\title{
Social Media Marketing - from Tool to Capability
}

Whereas the application of social media marketing has been trending in business, the theoretical research that analyses the phenomenon of social media marketing is to some extent lagging behind. In practice, social media marketing is often viewed as a customer relationship management (CRM) tool or technique and not as a capability. This paper builds on the theories of the resourced-based view (RBV) and dynamic capabilities to explore the concept of social media marketing capability. The aim of this paper is to redefine the phenomenon of social media marketing capability and to contribute to the existing literature. In addition, it urges firms to look into social media marketing not only as a tool or technique, but also as an organizational capability.

Keywords: social media marketing, social media marketing capability, resource-based view (RBV), dynamic capabilities.

Nepaisant to, kad rinkodaros socialinèse medijose taikymas versle plinta sparčiai, teoriniai tyrimai, analizuojantys ši fenomeną, tam tikru mastu atsilieka. Rinkodara socialinèse medijose praktikoje dažnai traktuojama kaip santykių su klientais valdymo (ang. Customer Relationship Management, CRM) technologija arba ịrankis, bet ne specialus įmonès gebejjimas. Šiame straipsnyje, remiantis ištekliais grịstu požiūriu (angl. Resource Based View, $R B V$ ) bei dinaminių gebejimų (angl. Dynamic Capabilities) teorijomis, plètojama rinkodaros socialinèse medijose gebejjimų sąvoka. Straipsnio tikslas - apibrěžti rinkodaros socialinèse medijose gebèjimų fenomeną taip prisidedant prie esamos mokslinès literatūros šia tema. Taip pat šiuo straipsniu siekiama pasiūlyti įmonèms ị rinkodarą socialinèse medijose žiūrèti ne tik kaip ị ịrankị, bet ir kaip ị organizacinị gebejjimą

Raktiniai žodžiai: rinkodara socialinèse medijose, rinkodaros socialinèse medijose gebejjimai, ištekliais grịstas požiūris, dinaminiai gebèjimai.

\section{Introduction}

Social media is often viewed as a groundbreaking Internet-related technology that has emerged over the last decades. J. H. Kietzmann et al. (2011) describe social media as web-based and mobile technologies that "create highly interactive platforms via which individuals and communities share, co-create, discuss, and modify user-generated content" (p. 241). It is no secret that the increased usage of social media in the last decade has changed the ways individuals communicate and access relevant information. In addition to this, the appearance of social media has not only affected the lives of individuals, but also opened up new avenues for firms to promote themselves. In other words, it has had a dramatic influence on the traditional model of marketing communications (Hanna, Rohm, Crittenden, 2011) and has significantly changed the tools and strategies for communicating with customers (Mangold, Faulds, 2009).

The rise of social media over the last years has drawn the interest of researchers and practitioners to acknowledge social 
media as a tool to better serve customers (Sashi, 2012). Given that the use of social media allows firms to engage in timely and direct contact with end customers at relatively low costs and high efficiency compared to traditional media (Kaplan, Haenlein, 2010), it is assumed that social media is relevant for firms of all sizes. On the other hand, given the relative (compared to, for example, traditional marketing channels) novelty of social media, firms still experience issues with regards to monetization and measurement of actions in social media. For instance, despite the common notion of social media being a very powerful tool, some firm executives still tend to ignore it and are incapable of developing strategies that would allow effective engagement within social media (Kietzmann et al., 2011) or still unwilling to view social media as one of the key elements of marketing strategy (Divol, Edelman, Sarrazin, 2012). This reluctance to acknowledge the power of this phenomenon may stem from the fact that firms do not fully understand how to use social media in an effective way or how to measure the performance of activities on social media (Hanna et al., 2011).

Despite the reluctance of some firm executives to acknowledge the phenomena of social media, marketing competencies that are shaped due to the existence of social media seem, to a large extent, to provide value for firms in reaching their marketing and strategic goals. This leads to a supposition that social media related activities should be acknowledged and developed within firms. Even though it has received much attention in recent years, both by practitioners and researchers, the understanding of social media and its implications with regards to marketing is still simplistic. In other words, social media marketing is typically viewed as a tool or technique and not as an organizational capability, which presents the problem of this paper. Thus, the research question of this paper is proposed as: "What groundwork theory constitutes the concept of social media marketing capability and how this concept can be redefined?"

The aim of this paper is to propose a thorough redefinition of social media marketing capability by examining the groundwork theory behind this concept and proposing why it should be viewed not only as a tool, but also as a capability. The objectives of the paper are:

- To describe the implications of social media marketing for firms;

- To explain social media marketing from the resource-based view (RBV) and dynamic capabilities theories;

- To suggest a redefinition of the social media marketing capability concept;

- To provide theoretical and managerial recommendations with regards to social media marketing activities.

In order to achieve the set objectives and the aim of this paper, a literature analysis method was applied.

\section{Social media marketing and its implications for firms}

The so-called Internet revolution in the 1990s led to the belief that the Internet is critical for the effective management of customer relationships (Novak, Hoffman, Yung, 2000). The technology facilitated marketing activities and introduced new ways of doing business 
as well as enhancing relationships with customers (Brodie et al., 2007). Similarly, the emergence of social media can be attributed to the revolution of the 2000s, given that the dissemination of information through social media appeared to be much faster compared to traditional media, such as TV, radio and print (Keller, 2009).

The growth of social media has been unlimited given the increasing investments by firms in social media (Kozinets et al., 2010). This phenomenon has become a new method of communication not only between its users, but also as a channel for firms to interact with its current and potential customers on a global scale. There are a number of ways in which the use of social media can be attributed to marketing activities performed by firms given the opportunities to leverage competitive advantage given the knowledge hidden in the textual data (He, $\mathrm{Zha}, \mathrm{Li}, 2013)$. Some of the key roles of social media in the marketing context are outlined as follows.

Customer engagement. According to R. Agnihotri et al. (2012), social media provides customer information based on customer-customer as well as company-customer interactions. Due to the empowerment of being able to respond to information provided by firms on social media, customers may feel engaged and over time may become more loyal to the firm. According to M. Durkin, P. McGowan and N. McKeown (2013), social media has become a catalyst in customer empowerment. This happens due to the interactivity of social media that enables information exchange not only between sellers and their customers, but also among customers themselves (Sashi, 2012). This interactivity provided by social media turns customers into the initiators and recipients of information exchange, where both of these processes happen simultaneously. Compared with traditional marketing techniques that focus solely on the firm-customer relationships, social media places a focus on customer-to-customer relationships as well and tends to yield greater consumer engagement (Trusov, Bucklin, Pauwels, 2009).

Enhancing relationships with customers. Social media technology facilitated marketing activities and introduced new ways of doing business as well as enhancing relationships with customers (Brodie et al., 2007). Social media is nowadays viewed a tool helps firms to develop long-lasting customer relationships (Trainor et al., 2014) that are essential in order to sustain or enhance performance. Social media enables organizations to create relationships with existing and potential customers, and helps to build interactive and collaborative communities, which allows firms to recognize and solve potential customer problems as well as helps improving customer relationship management processes within firms.

Information dissemination. Upon the arrival of a new generation of interactive technologies, namely social networks, blogs, forums and others, the market power shifted from the firm to the consumer. Therefore, social media enables information dissemination among consumers given that the content has become easy to create, publish and disseminate. According to E. Constantinides and 
S. T. Fountain (2008), social media allows firms to create consumer "communities" where they discuss products, services and brands as well as participate in the product development processes, in other words, share information. W. G. Mangold and D. J. Faulds (2009) claim that social media has become a key contributor to influencing consumer behaviour in terms of awareness, acquiring information, opinions, attitudes as well as purchase and post-purchase behaviour.

Enhanced reach and targeting. Social media is considered to be a tool that is used to connect to customers, enabling wider media expansion and a larger reach (Thackeray et al., 2008). This phenomenon has become a new method of communication not only between its users, but also as a channel for firms to interact with its current and potential customers on a global scale (Chu, Kim, 2011). Furthermore, due to its uniqueness, social media allows potential customers to be targeted based on their demographic and psychographic characteristics, which proves its importance in the international and customer targeting contexts (Constantinides, Fountain, 2008).

Acknowledging social media in marketing research. With respect to previous research studies, it is clear that since the emergence of social media applications like Facebook (Hoffman, Fodor, 2010) it has changed and transformed the way in which firms perform their marketing activities. The role of social media in marketing strategies has been the focus of previous research studies. For example, a study by M. Bruhn, V. Schoenmueller and D. B. Schäfer (2012) investigated the impact of brand communication on brand equity through social media comparing it with traditional media and found that both traditional and social media communications significantly affect brand equity. Traditional media was found to be stronger in terms of brand awareness, whereas social media communications were discovered to strongly impact brand image. J. Braojos-Gomez, J. Benitez-Amado and F. J. Llorens-Montes (2015) found that information technology infrastructure capability, social competitor pressure, marketing management and innovation management are the critical means for firms to learn how to develop social media competence.

While social media is used for many purposes, both by individuals and enterprises as a source of information or as a marketing communication instrument, it can be assumed that social media has a large influence on the success of a firm, and the importance and growth of it seems unlimited (Trusov et al., 2009). Moreover, the emergence of social media has urged marketers to shift their marketing expenditure and instead of investing in traditional channels, has shifted the emphasis to networks that can reach consumers online. Thus, firms are in need of social media marketing competencies on an organizational level that should be deployed in order to add to firms' competitive advantage. However, the question of what social media marketing capability actually is still remains rather undetermined in the theoretical research. 


\section{Social media from a capability-based perspective}

The theories of the resource-based view $(R B V)$ and dynamic capabilities serve as the theoretical foundations of this paper in order to understand the phenomenon of social media marketing capability. The RBV as a viewpoint to explain a firm's performance argues that the resources of the firm determine and define its performance (Wernerfelt, 1984). The RBV therefore refers to the theory stating that valuable, rare, inimitable and nonsubstitutable resources contribute to sustaining the competitive advantage of a firm, and the performance of a firm is determined by its heterogeneous resources (Barney, 1991).

As the RBV stems from the notion that firms strategize based on their resources and capabilities in order to achieve a competitive advantage and subsequently improve their performance (Barney, 1991), it is assumed that technological resources and their successive capabilities can become a source to achieve a competitive advantage both in a national and international context (Filipescu, Rialp \& Rialp, 2009; Filipescu et al., 2013). Thus, more specifically, being able to exploit social media channels to adjust a firm's strategic marketing actions could lead to an enhanced competitive advantage and subsequently improved performance.

Since its introduction, the RBV has often received criticism due to its inability to consistently and reliably explain the development and deployment of resources that are intended to enable a firm to perform better and to gain a competitive advantage against other firms (Priem, Butler, 2001). It has also been criticized for overlooking the importance of dynamic market environments (Lengnick-Hall, Wolf, 1999). The RBV theory is static, and therefore it does not properly explain what drives the competitive advantage of a firm when business-related environmental changes occur in the marketplace (Teece, Pisano, Shuen, 1997).

To address the limitations of the RBV theory, the perspective of dynamic capabilities has become increasingly popular over the last decades. Dynamic capability is defined as "the firm's ability to integrate, build, and reconfigure internal and external competences to address rapidly changing environments" (Teece et al., 1997, p. 516). Dynamic is related to the ability to renew competences in order to adjust to environmental changes in the business-related context and capabilities describe the competencies of adapting, integrating and reconfiguring organizational skills as well as resources in order to stay competitive in an environment that is competitive and rapidly changing.

Initially, marketplaces are viewed as dynamic environments in addition to addressing the heterogeneity of the firm's resources (Morgan, Vorhies, Mason, 2009). D. J. Teece et al. (1997) state that dynamic capabilities are strategically important for firms that operate in fastchanging and turbulent environments due to their ability to respond to environmental uncertainties. Thus, dynamic capabilities are viewed as a combination of the resources of the firm and its environment; they are gained and deployed, and can explain the performance of the 
firm (Einsenhardt, Martin, 2000). Dynamic capabilities are also defined as "the firm's processes that use resources specifically the processes to integrate, reconfigure, gain and release resources to match and even create market change; dynamic capabilities thus are the organizational and strategic routines by which firms achieve new routines by which firms achieve new resource configurations as markets emerge, collide, split, evolve, and die" (Eisenhardt, Martin, 2000, p. 1107).

Firms that operate in turbulent and constantly changing business environments may benefit from real-time market information. Therefore, it is important for firms to obtain relevant resources and competencies to take advantage of realtime market information that can benefit them. When operating in chaotic and turbulent environments, firms have to cultivate unique individual resources and competencies in order to build a competitive advantage against other firms (Hitt, Keats, DeMarie, 1998). Social media with its knowledge in the textual data (He et al., 2013) may be linked to providing firms with opportunities to leverage competitive advantage.

Henceforth, this paper uses the dynamic capabilities theory to provide an understanding of how social media channels can be deployed to shape the capabilities that generate advantages for firms (Wade, Hulland, 2004). According to $\mathrm{K}$. J. Trainor et al. (2011), if resources are deployed efficiently, it may lead to an improvement in the firm's ability to adapt to its competitive environment, where adaptability relates to the extent a firm can deploy various organizational capabilities (Sanchez, Mahoney, 1996) and to implement strategic changes (Oktemgil, Greenley, 1997).

Whereas innovative capability is considered to stem from a firm's internal innovation, which creates a competitive advantage (Barney, 1991), technological capability may also refer to the extent to which a firm is able to exploit external technologies. As indicated by previous research, to compete with others, firms should generate their competitive advantage through innovation (Cho, Pucik, 2005) as well as the development of new capabilities (Grant, 1996; Danneels, 2002; Branzei, Vertinsky, 2006), which makes technology an important factor in increasing the competitiveness of a firm. Therefore, it can be assumed that interactive technologies such as social media can stimulate a firm's dynamic capabilities on an organizational level and, if exploited in a relevant manner, can lead to a competitive advantage and thus enhance a firm's performance. In other words, social media should be combined with marketing capabilities in order to drive the competitive advantage of a firm.

\section{Acknowledging customer relationship management in social media marketing}

Social media channels, such as Facebook, LinkedIn, Instagram, Snapchat, Twitter, etc., have, in recent years, been adopted by Internet users in order to connect with peers as well as firms (Berthon et al., 2012; Hanna et al., 2011, Rainie, Purcell, Smith, 2011). Firms have been faced with the challenge of deploying novel 
technologies and capabilities in order to facilitate interactions with their customers (Andzulis, Panagopoulos, Rapp, 2012; Trainor, 2012). Thus, previous research has suggested that social media marketing activities deployed by firms are inseparable from customer relationship management (CRM) activities.

CRM refers to the idea that a firm is required to understand its market and customers in order to demonstrate a successful performance (Rygielski, Wang, Yen, 2002). W. Boulding et al. (2005) defines CRM as "strategy, the management of the dual creation of value, the intelligent use of data and technology, the acquisition of customer knowledge and the diffusion of this knowledge to the appropriate stakeholders, the development of appropriate (long-term) relationships with specific customers and/or customer groups, and the integration of processes across the many areas of the firm and across the network of firms that collaborate to generate customer value" (p. 157). This definition acknowledges CRM as a strategy as well as a method for implementing information technology, which then correspondingly supports marketing activities that creates customer value (Trainor, 2012). The critical information development processes that are influenced by a firm's technology and strategic orientation have an impact on CRM technology outcomes (Jayachandran et al., 2005).

The emergence of social media has pushed firms to move their CRM activities towards the base of their customers and changed the traditional perception of CRM. Whereas the traditional notion of CRM considered the role of the customer as passive, with the rise of social media, customers became active users and disseminators of information. To address the move from the traditional view of CRM towards the incorporation of social media technologies and their consequent impact on resources and capabilities, a new term, "social CRM", was coined by Greenberg (2010). "Social CRM", based on P. Greenberg's (2010) definition, is "the integration of traditional customer-facing activities including processes, systems, and technologies with emergent social media applications to engage customers in collaborative conversations and enhance customer relationships." The rise of social media provided firms with opportunities to listen to and to engage with their customers, who could then consequently spread positive information about their products or services (Malthouse et al., 2013). A novel approach of "social CRM" extended the traditional CRM approach into a more collaborative and network-focused concept that enables better customer relationship management.

The "social CRM" approach recognizes the importance of interactions between the firm and its customers through social media applications, which supports the notion of A. M. Kaplan and M. Haenlein (2010), who claim that the interactivity between consumers and businesses is made possible through social media adoption. According to L. Rainie et al. (2011), social media applications encourage interactivity among network members where interactivity is expected to happen in both personal and business networks. 
According to K. J. Trainor (2012), managing customer relationships through social media positively influences consumer engagement and correspondingly creates value from those interactions, which may have a dramatic positive impact on firm performance. "Social CRM" acknowledges the value created by technological and social changes from social media applications. K. J. Trainor (2012) extends the traditional view of CRM by including the perspective of social media technologies and providing suggestions of how these technologies can have an impact on a firm's performance. He, thus, defined social CRM capability as "the integration of traditional customer-facing activities, including processes, systems, and technologies with emergent social media applications to engage customers in collaborative conversations and enhance customer relationships" (Trainor, 2012, p. 321).

Thus, taking the above into consideration, the role of CRM has to be acknowledged when redefining the concept of social media marketing competencies,

\section{Redefining social media marketing capability}

Having provided the argumentation why social media marketing capabilities should be based upon the resourcebased view (RBV) and dynamic capabilities theory and linked to customer relationship management (CRM), this paper continues towards redefining the concept of social media marketing capability.
Information technology, primarily the Internet and social media, has radically changed the landscape of marketing activities used by firms (Sinkovics, Sinkovics, Jean, 2013) given such benefits as real-time feedback on products or their ideas, opportunities to build communities among customers or seeking brand awareness (Constantinides, Fountain, 2008).

Firms relying on information technology, especially the Internet, have been able to improve their customer service management as well as firm performance (Jean, Sinkovics, 2010; Jean, Sinkovics, Kim, 2008; Liang, You, Liu, 2010; Liu et al., 2013; Ray, Muhanna, Barney, 2005; Trainor et al., 2011). Thus, social media competencies are considered to be a cohesive set of technologic resources that may lead to a competitive advantage and improve firm performance, given a more efficient information management system (Trainor et al., 2014).

According to J. H. Kietzmann et al. (2011), social media enables content dissemination between customers and firms. Additionally, social media may generate better access to customer information given the customer-to-customer or firm-to-customer interactions (Agnihotri et al., 2012). Social media has been acknowledged by customers due to the connectivity it provides. Customers therefore tend to expect that companies will also interact with them (Berthon et al., 2012; Hanna et al., 2011; Rainie et al., 2011; Trainor et al., 2014).

Firms are therefore faced with the challenge of facilitating more interactions with customers by deploying new technologies and capabilities (Andzulis 
et al., 2012; Trainor, 2012). As mentioned earlier, J. Barney (1991) explains the RBV as a theory that clarifies how strategies are adopted by firms based on their strategic resources and capabilities in order to achieve a sustainable competitive advantage and thus improve firm performance. Thus, technologies and particularly information technology capabilities can lead to a sustainable competitive advantage (Filipescu et al., 2013).

Evaluation of a firm's competitive advantage refers to information collection about customer perceptions of products and services offered by the firm as well as the investigation of its explanatory factors such as resources and capabilities in comparison to the firm's competitors in the market (Navarro et al., 2010). However, previous research suggests that the resources of the firm do not contribute to increased performance alone but have to be converted into distinctive capabilities. Therefore, media channels from a firm's marketing perspective may be worthless on their own without fully exploiting the potential of applying organizational capabilities to make the best out of the channels. This leads to the supposition that social media marketing capability will occur only when the technological resources (social media channels) are deployed in combination with complementary organizational resources (Melville, Kraemer, Gurbaxani, 2004). In other words, firms should be capable of deploying social media channels in order to yield performance improvements. Dynamic capabilities do not guarantee enhanced organizational performance; however, according to K. M. Eisenhardt and J. A. Martin (2000), dynamic capabilities are crucial when aiming at enhancing firm performance.

C. E. Helfat (1997) notes that dynamic capability refers to the decisive capability enabling firms to develop new products or new processes to respond to market changes. Discussion on marketing capabilities and information technology leads to a supposition that the two are the antecedents of social media marketing capabilities. Social media technology as information technology, supported by marketing capabilities of a firm can be viewed as social media marketing capability that is essential for firms in order to catch up with growing social media use among customers in order to generate, disseminate and respond to information gathered from social media channels.

With the help of social media, firms have been empowered to facilitate their interactions with customers by developing new capabilities (Trainor et al., 2014). Social media marketing capability is inseparable from customers and relates to a firm's ability to generate, disseminate and respond to information, which is gathered from customers on social media. Thus, social media marketing capability extends the definition of social CRM capability and is described as a firm's competency by generating, disseminating and responding to information gathered from customers via social media channels to improve customer engagement and thus satisfaction, loyalty, and retention.

\section{Recommendations and conclusions}

Given that the popularity of social media marketing is growing, both in a 
theoretical and practical sense, this paper contributes to future research studies with regards to the understanding of the social media marketing capability concept. This is line with observations in the recent scientific literature that see the exploitation of social media as well other tools of information technology signifying a critical, but to large extent untapped topic in strategy processes and indicates the need for future research in this area (Baptista et al., 2017).

The results of the literature analysis provided in this paper are twofold. First, it provides theoretical contribution to the existing literature on social media marketing. This paper overviewed the groundwork theory behind the concept of social media marketing capability. Based on the resource-based view (Barney, 1991) and dynamic capabilities (Teece, 1997) theory, in light of the common notion of the vitality of social media and its importance in supporting marketing actions of firms, the concept of social media marketing capabilities was redefined. As a consequence, it was proposed for future research studies to view this concept not only as a tool, but also as a strategic capability that can help in adjusting firm's marketing strategy and thus enhance performance. Besides, social media marketing capability was identified as being closely linked to the customer relationship management (CRM) concept, which should also be acknowledged in the future research studies.

Second, besides the theoretical contribution, this paper suggests several managerial recommendations with regards to social media implementation within firms. The existence of social media empowers firms and their representatives to first conceptualize the overall marketing strategy of firms and not solely focus on tactics, which should instead follow a well thought-out marketing strategy (Hanna et al., 2011). Keeping in mind that social media has become a vital part of firms' marketing activities with regards to existing and potential customers, it is proposed that social media should support a firm's marketing strategy. Thus, social media should not be a standalone tool that is incorporated into the marketing plan; instead, companies should adjust their marketing strategies with regards to different media for various purposes such as launching and promoting a new product or service, communicating new firm initiatives or simply engaging customers (Hanna et al., 2011). Moreover, in order to cultivate effective marketing strategy, reaching customers is not enough and efforts should be focused on capturing the attention of and engaging customers, which calls for both traditional and social media channels to be incorporated into the marketing strategies of firms (Hanna et al., 2011). Hence, social media marketing capabilities should be developed within firms and involved in the formulation of firms' marketing strategies, which should lead to improving relationships with customers and performance as follows. Despite the fact that social media marketing capabilities do not necessarily guarantee improved performance, they are vital when aiming to achieve a competitive advantage. Thus, it is proposed for firms to invest in technological resources (social 
media) in combination with complementary organizational resources to improve performance. This suggests that firms should invest in improving social media marketing capabilities on an organizational level.
Future research studies acknowledging the concept of social media marketing capability may expand by surveying firms to gain insights of their understanding of the concept and its impact on marketing strategies and performance.

\section{References}

1. Agnihotri, R., Kothandaraman, P., Kashyap, R., Singh, R. (2012). Bringing "Social" into Sales: The Impact of Salespeople's Social Media Use on Service Behaviors and Value Creation // Journal of Personal Selling \& Sales Management. Vol. 32(3), pp. 333-348. doi: 10.2753/ PSS0885-3134320304.

2. Andzulis, J. M., Panagopoulos, N. G., Rapp, A. (2012). A Review of Social Media and Implications for the Sales Process // Journal of Personal Selling \& Sales Management. Vol. 32(3), pp. 305316. doi: 10.2753/PSS0885-3134320302.

3. Baptista, J., Wilson, A. D., Galliers, R. D., Bynghall, S. (2017). Social Media and the Emergence of Reflexiveness as a New Capability for Open Strategy // Long Range Planning. Vol. 50(3), pp. 322-336. doi: 10.1016/j.lrp.2016.07.005.

4. Barney, J. (1991). Firm Resources and Sustained Competitive Advantage // Journal of Management. Vol. 17(1), pp. 99-120. doi: 10.1016/ S0742-3322(00)17018-4.

5. Berthon, P. R., Pitt, L. F., Plangger, K., Shapiro, D. (2012). Marketing Meets Web 2.0, Social Media, and Creative Consumers: Implications for International Marketing Strategy // Business Horizons. Vol. 55(3), pp. 261-271. doi: 10.1016/j.bushor.2012.01.007.

6. Boulding, W., Staelin, R., Ehret, M., Johnston, W. J. (2005). A Customer Relationship Management Roadmap: What is Known, Potential Pitfalls, and Where to Go // Journal of Marketing. Vol. 69(4), pp. 155-166. doi: 10.1509/ jmkg.2005.69.4.155.

7. Branzei, O., Vertinsky, I. (2006). Strategic Pathways to Product Innovation Capabilities in SMEs // Journal of Business Venturing. Vol. 21(1), pp. 75-105. doi: 10.1016/j.jbusvent.2004.10.002.
8. Braojos-Gomez, J., Benitez-Amado, J., LlorensMontes, F. J. (2015). How do Small Firms Learn to Develop a Social Media Competence? // International Journal of Information Management. Vol. 35(4), pp. 443-458. doi: 10.1016/j. ijinfomgt.2015.04.003.

9. Brodie, R. J., Winklhofer, H., Coviello, N. E., Johnston, W. J. (2007). Is e-Marketing Coming of Age? An Examination of the Penetration of eMarketing and Firm Performance // Journal of Interactive Marketing. Vol. 21(1), pp. 2-21. doi: 10.1002/dir.20071.

10. Bruhn, M., Schoenmueller, V., Schäfer, D. B. (2012). Are Social Media Replacing Traditional Media in Terms of Brand Equity Creation? // Management Research Review. Vol. 35(9), pp. 770-790. doi: 10.1108/01409171211255948.

11. Cho, H. J., Pucik, V. (2005). Relationship between Innovativeness, Quality, Growth, Profitability, and Market Value // Strategic Management Journal. Vol. 26(6), pp. 555-575. doi: $10.1002 /$ smj.461.

12. Chu, S. C., Kim, Y. (2011). Determinants of Consumer Engagement in Electronic Wordof-Mouth (eWOM) in Social Networking Sites // International Journal of Advertising. Vol. 30(1), pp. 47-75. doi: 10.2501/ IJA-30-1-047-075.

13. Constantinides, E., Fountain, S. J. (2008). Web 2.0: Conceptual Foundations and Marketing Issues // Journal of Direct, Data and Digital Marketing Practice. Vol. 9(3), pp. 231-244. doi: $10.1057 /$ palgrave.dddmp.4350098.

14. Danneels, E. (2002). The Dynamics of Product Innovation and Firm Competences // Strategic Management Journal. Vol. 23(12), pp. 10951121. doi: 10.1002/smj.275. 
15. Divol, R., Edelman, D., Sarrazin, H. (2012). Demystifying Social Media // McKinsey Quarterly. Vol. 2(12), pp. 66-77.

16. Durkin, M., McGowan, P., McKeown, N. (2013). Exploring Social Media Adoption in Small to Medium-Sized Enterprises in Ireland // Journal of Small Business and Enterprise Development. Vol. 20(4), pp. 716-734. doi: 10.1108/ JSBED-08-2012-0094.

17. Eisenhardt, K. M., Martin, J. A. (2000). Dynamic Capabilities: What are they? // Strategic Management Journal. pp. 1105-1121. doi: 10.1002/1097- 0266(200010/11)21:10/11<1105: :AID-SMJ133>3.0.CO;2-E.

18. Filipescu, D. A., Prashantham, S., Rialp, A., Rialp, J. (2013). Technological Innovation and Exports: Unpacking Their Reciprocal Causality // Journal of International Marketing. Vol. 21(1), pp. 23-38. doi: doi.org/10.1509/jim.12.0099.

19. Filipescu, D. A., Rialp, A., Rialp, J. (2009). Internationalisation and Technological Innovation: Empirical Evidence on Their Mutual Relationship / In New Challenges to International Marketing (pp. 125-154). Emerald Group Publishing Limited.

20. Grant, R. M. (1996). Toward a KnowledgeBased Theory of the Firm // Strategic Management Journal. Vol. 17(S2), pp. 109-122. doi: 10.1002/smj.4250171110.

21. Greenberg, P. (2010). The Impact of CRM 2.0 on Customer Insight // Journal of Business \& Industrial Marketing. Vol. 25(6), pp. 410-419. doi: 10.1108/08858621011066008.

22. Hanna, R., Rohm, A., Crittenden, V. L. (2011). We're all Connected: The Power of the Social Media Ecosystem // Business Horizons. Vol. 54(3), pp. 265-273. doi: 10.1016/j.bushor.2011.01.007.

23. He, W., Zha, S., Li, L. (2013). Social Media Competitive Analysis and Text Mining: A Case Study in the Pizza Industry // International Journal of Information Management. Vol. 33(3), pp. 464472. doi: 10.1016/j.ijinfomgt.2013.01.001.

24. Helfat, C. E. (1997). Know-How and Asset Complementarity and Dynamic Capability Accumulation: The Case of R\&D // Strategic Management Journal. pp. 339-360. doi: 10.1002/ (SICI) 1097-0266(199705) 18:5<339::AIDSMJ883>3.0.CO;2-7.

25. Hitt, M. A., Keats, B. W., DeMarie, S. M. (1998). Navigating in the New Competitive Landscape:
Building Strategic Flexibility and Competitive Advantage in the 21st Century // The Academy of Management Executive. Vol. 12(4), pp. 2242. doi: 10.5465/AME.1998.1333922.

26. Hoffman, D. L., Fodor, M. (2010). Can you Measure the ROI of Your Social Media Marketing? // MIT Sloan Management Review. Vol. 52(1), p. 41.

27. Jayachandran, S., Sharma, S., Kaufman, P., Raman, P. (2005). The Role of Relational Information Processes and Technology Use in Customer Relationship Management // Journal of Marketing. Vol. 69(4), pp. 17s7-192. doi: 10.1509/ jmkg.2005.69.4.177.

28. Jean, R. J., Sinkovics, R. R. (2010). Relationship Learning and Performance Enhancement via Advanced Information Technology: The Case of Taiwanese Dragon Electronics Firms // International Marketing Review. Vol. 27(2), pp. 200222. doi: 10.1108/02651331011037520.

29. Jean, R. J., Sinkovics, R. R., Kim, D. (2008). Information Technology and Organizational Performance within International Business to Business Relationships: A Review and an Integrated Conceptual Framework // International Marketing Review. Vol. 25(5), pp. 563-583. doi: 10.1108/02651330810904099.

30. Kaplan, A. M., Haenlein, M. (2010). Users of the World, Unite! The Challenges and Opportunities of Social Media // Business Horizons. Vol. 53(1), pp. 59-68. doi: 10.1016/j. bushor.2009.09.003.

31. Keller, K. L. (2009). Building Strong Brands in a Modern Marketing Communications Environment // Journal of Marketing Communications. Vol. 15(2-3), pp. 139-155. doi: $10.1080 / 13527260902757530$.

32. Kietzmann, J. H., Hermkens, K., McCarthy, I. P., Silvestre, B. S. (2011). Social Media? Get Serious! Understanding the Functional Building Blocks of Social Media // Business Horizons. Vol. 54(3), 241-251. doi: 10.1016/j.bushor.2011.01.005.

33. Kozinets, R. V., De Valck, K., Wojnicki, A. C., Wilner, S. J. (2010). Networked Narratives: Understanding Word-of-Mouth Marketing in Online Communities // Journal of Marketing. Vol. 74(2), pp. 71-89. doi: 10.1509/jmkg.74.2.71.

34. Lengnick-Hall, C. A., Wolff, J. A. (1999). Similarities and Contradictions in the Core Logic of three Strategy Research Streams // Strategic Management Journal. pp. 1109-1132. doi: 10.1002/ 
(SICI) 1097-0266(199912)20:12<1109::AIDSMJ65>3.0.CO;2-8.

35. Liang, T. P., You, J. J., Liu, C. C. (2010). A Resource-based Perspective on Information Technology and Firm Performance: A Meta Analysis // Industrial Management \& Data Systems. Vol. 110(8), pp. 1138-1158. doi: 10.1108/02635571011077807.

36. Liu, H., Ke, W., Wei, K. K., Hua, Z. (2013). The Impact of IT Capabilities on Firm Performance: The Mediating Roles of Absorptive Capacity and Supply Chain Agility // Decision Support Systems. Vol. 54(3), pp. 1452-1462. doi: 10.1016/j. dss.2012.12.016.

37. Malthouse, E. C., Haenlein, M., Skiera, B., Wege, E., Zhang, M. (2013). Managing Customer Relationships in the Social Media Era: Introducing the Social CRM House // Journal of Interactive Marketing. Vol. 27(4), pp. 270-280. doi: 10.1016/j.intmar.2013.09.008.

38. Mangold, W. G., Faulds, D. J. (2009). Social Media: The New Hybrid Element of the Promotion Mix // Business Horizons. Vol. 52(4), pp. 357365. doi: 10.1016/j.bushor.2009.03.002.

39. Melville, N., Kraemer, K., Gurbaxani, V. (2004). Information Technology and Organizational Performance: An Integrative Model of IT Business Value // MIS Quarterly. Vol. 28(2), pp. 283322. doi: $10.2307 / 25148636$.

40. Morgan, N. A., Vorhies, D. W., Mason, C. H. (2009). Market Orientation, Marketing Capabilities, and Firm Performance // Strategic Management Journal. Vol. 30(8), pp. 909-920. doi: 10.1002/smj.764.

41. Navarro, A., Losada, F., Ruzo, E., Díez, J. A. (2010). Implications of Perceived Competitive Advantages, Adaptation of Marketing Tactics and Export Commitment on Export Performance // Journal of World Business. Vol. 45(1), pp. 49-58. doi: 10.1016/j.jwb.2009.04.004.

42. Novak, T. P., Hoffman, D. L., Yung, Y. F. (2000). Measuring the Customer Experience in Online Environments: A Structural Modeling Approach // Marketing science. Vol. 19(1), pp. 2242. doi: $10.1287 / \mathrm{mksc}$.19.1.22.15184.

43. Oktemgil, M., Greenley, G. (1997). Consequences of High and Low Adaptive Capability in UK Companies // European Journal of Marketing. Vol. 31(7), pp. 445-466. doi: 10.1108/03090569710176619.
44. Priem, R. L., Butler, J. E. (2001). Is the ResourceBased "View" a Useful Perspective for Strategic Management Research? // Academy of Management Review. Vol. 26(1), pp. 22-40. doi: $10.2307 / 259393$.

45. Rainie, L., Purcell, K., Smith, A. (2011). The Social Side of the Internet. "Pew Internet \& American Life Project". Internet access: http://www.pewinternet.org/2011/01/18/ the-social-side-of-the-internet/

46. Ray, G., Muhanna, W. A., Barney, J. B. (2005). Information Technology and the Performance of the Customer Service Process: A Resourcebased Analysis // MIS Quarterly. Pp. 625-652. doi: $10.2307 / 25148703$.

47. Rygielski, C., Wang, J. C., Yen, D. C. (2002). Data Mining Techniques for Customer Relationship Management // Technology in Society. Vol. 24(4), pp. 483-502. doi: 10.1016/ S0160-791X(02)00038-6.

48. Sanchez, R., Mahoney, J. T. (1996). Modularity, Flexibility, and Knowledge Management in Product and Organization Design // Strategic Management Journal. Vol. 17(S2), pp. 63-76. doi: 10.1002/smj.4250171107.

49. Sashi, C. M. (2012). Customer Engagement, Buyer-Seller Relationships, and Social Media // Management Decision. Vol. 50(2), pp. 253-272. doi: 10.1108/00251741211203551.

50. Sinkovics, N., Sinkovics, R. R., "Bryan" Jean, R. J. (2013). The Internet as an Alternative Path to Internationalization? // International Marketing Review. Vol. 30(2), pp. 130-155. doi:10.1108/02651331311314556.

51. Teece, D. J., Pisano, G., Shuen, A. (1997). Dynamic Capabilities and Strategic Management // Strategic Management Journal. Vol. 18(7), pp. 509-533. doi:10.1002/ (SICI)1097-0266(199708)18:73.0.CO;2-Z.

52. Thackeray, R., Neiger, B. L., Hanson, C. L., McKenzie, J. F. (2008). Enhancing Promotional Strategies within Social Marketing Programs: Use of Web 2.0 Social Media // Health Promotion Practice. Vol. 9(4), pp. 338-343. doi: $10.1177 / 1524839908325335$.

53. Trainor, K. J. (2012). Relating Social Media Technologies to Performance: A Capabilitiesbased Perspective // Journal of Personal Selling \& Sales Management. Vol. 32(3), pp. 317-331. doi: 10.2753/PSS0885-3134320303. 
54. Trainor, K. J., Andzulis, J. M., Rapp, A., Agnihotri, R. (2014). Social Media Technology Usage and Customer Relationship Performance: A Capabilities-based Examination of Social CRM // Journal of Business Research. Vol. 67(6), pp. 1201-1208. doi: 10.1016/j. jbusres.2013.05.002.

55. Trainor, K. J., Rapp, A., Beitelspacher, L. S., Schillewaert, N. (2011). Integrating Information Technology and Marketing: An Examination of the Drivers and Outcomes of e-Marketing Capability // Industrial Marketing Management. Vol. 40(1), pp. 162-174. doi: 10.1016/j. indmarman.2010.05.001.

56. Trusov, M., Bucklin, R. E., Pauwels, K. (2009). Effects of Word-of-Mouth Versus Traditional
Marketing: Findings from an Internet Social Networking Site // Journal of Marketing. Vol. 73(5), pp. 90-102. doi: 10.2139/ssrn.1129351.

57. Wade, M., Hulland, J. (2004). The Resourcebased View and Information Systems Research: Review, Extension, and Suggestions for Future Research // MIS Quarterly. Vol. 28(1), pp. 107142. doi: $10.2307 / 25148626$.

58. Wernerfelt, B. (1984). A Resource-based View of the Firm // Strategic Management Journal. Vol. 5(2), pp. 171-180. doi: 10.1002/ smj.4250050207.

The paper submitted: May 21, 2018 Prepared for publication: June 29, 2018

\section{Dominyka VENCIŪTÉ \\ RINKODARA SOCIALINĖSE MEDIJOSE - NUO ĮRANKIO IKI GEBĖJIMO}

\section{S a n t r a k a}

Pastarąji dešimtmetị socialinès medijos pakeitè ne tik individų gyvenimus bendravimo vienų su kitais kontekste, bet atvèrè ir naujas galimybes verslui, darydamos ịtaką tradiciniam rinkodaros komunikacijos supratimui. Suteikdamos galimybes i̇monèms bendrauti su savo vartotojais, skatinti jų įsitraukimą, sudaryti sąlygas keistis informacija tarp vartotojų, pasiekti tikslinę auditoriją ir kt., socialinès medijos leidžia įmonèms ịtvirtinti konkurencinị pranašumą. Tam, kad galètų jị kurti, imonèms reikalingos organizacinio lygmens rinkodaros socialinèse medijose kompetencijos. Nors rinkodara socialinèse medijose versle sparčiai plinta, teoriniai tyrimai, analizuojantys rinkodaros socialinèse medijose fenomeną, atsilieka. Rinkodara socialinèse medijose dažniausiai vertinama kaip įrankis, tačiau ne kaip organizacinis gebejjimas. Tai leidžia kelti šio tyrimo klausimą: „Kokios teorijos sąlygoja rinkodaros socialinèse medijose gebejimo fenomeną ir kaip šio fenomeno apibrežzimas galètų būti atnaujintas?“

Šio darbo tikslas - apibrěžti rinkodaros socialinèse medijose gebejjimus, taip prisidedant prie esamos mokslinès literatūros šia tema. Tikslams pasiekti formuluojami šie uždaviniai:

- Apibūdinti socialinių medijų reikšmę i̇monèms.

- Paaiškinti rinkodarą socialinėse medijose remiantis ištekliais pagrịstu požiūriu (angl. Resource Based View, RBV) bei dinaminių gebejjimų (angl. Dynamic Capabilities) teorijomis.

- Pasiūlyti atnaujintą rinkodaros socialinėse medijose gebèjimų apibrěžimą.

- Pateikti teorines ir vadybines rekomendacijas rinkodaros veikloms socialinių medijų kontekste.

Tikslui pasiekti tyrimo metodu buvo pasirinkta mokslinès literatūros analizè remiantis užsienio mokslininkų atliktomis stebėsenomis bei analizèmis.

Analizès metu paaiškejo, kad rinkodaros socialinèse medijose gebejjimas gali būti paaiškintas kaip dinaminis gebejimas, i̇monèms reikalingas norint prisitaikyti prie pokyčių verslo aplinkoje integruojant ir perkonfigūruojant organizacinius igūdžius bei išteklius. Šis prisitaikymas įmonei reikalingas norint išlaikyti konkurencinį prana- 
šumą konkurencingoje bei nuolat kintamoje verslo aplinkoje. Taip pat išsiaiškinta, kad rinkodara socialinèse medijose neatsiejama nuo santykių su klientais valdymo (angl. Customer Relationship Management, CRM).

Straipsnyje pasiūlytas rinkodaros socialinèse medijose gebejjimo apibrèžimas, kuris šị feno- meną apibūdino kaip įmonès gebejjimą pagerinti vartotojų ísitraukimą, pasitenkinimą, lojalumą bei išlaikymą generuojant, skleidžiant bei reaguojant i socialinių medijų kanalais iš vartotojų gautą informaciją. Taip pat, pasiūlyta ịmonèms ị rinkodarą socialinèse medijose žiūrèti ne tik kaip ị ịrankị, bet kartu, kaip ị organizacinị gebejjimą. 